\title{
The Nature of the Original "Firm": A Coasean Cost-Benefit Analysis of Legalizing Prostitution
}

\author{
By Malia Dalesandry
}

Though there have been many studies of prostitution from the legal perspective, the feminist perspective, the societal perspective, and the moral, ethical, and religious perspective, the current breadth of literature does not include a costbenefit analysis from which to examine its economic effects. This paper attempts a comprehensive analysis of legalizing prostitution while noting deficiencies in data and recognizing variations when interpreting existing data. The most salient monetary costs and benefits are discussed and calculated, and many others are included for the sake of a more developed examination. After $a$ sensitivity analysis and a brief discussion of how Coase's theorem may be utilized to determine economic efficiency, the conclusion and final recommendation is that, because economic benefits vastly outweigh economic costs, all states could benefit economically from legalizing prostitution.

\section{Introduction}

Often called the world's oldest profession, prostitution has long been regarded as a blight on society, a moral shortcoming on the part of the engaged parties, and a failure of humanity that the practice of selling sexual acts continues to occur. In his book "Defending the Undefendable," Walter Block notes that, despite the fact that selling sex is illegal and has many attached hazards, prostitutes' services are continuously sought out (Block 2008). Perhaps the crux of the matter is that a transaction which society deems socially repugnant is not necessarily economically inconsistent, but rather is also subject to the same tendencies and constraints as any other market. Following that, perhaps the best solution to deal with society's repugnance and concerns is one based upon an economic approach toward perceived moral or ethical problems. Therefore, we conduct a detailed cost-benefit analysis to determine whether the status quo (prostitution's illegality) is in fact the best policy, or whether the practice should be legalized. Currently legal in some parts of Nevada, prostitution is not federally illegal, except within some specific parameters regarding children and transportation; thus, the policy change considered is that all states legalize consensual prostitution among adults.

In order to appreciate this analysis from a purely economic perspective, prostitution must be accepted as having similar attributes and tendencies as any other transaction; personal ideologies must be set aside in order to reach objective conclusions. American society permits a myriad of activities that many citizens would not condone, including pornography, the distribution of alcohol and tobacco products (and even marijuana products, in some jurisdictions), gambling, and violent sporting events, such as boxing matches. That these activities are not prohibited, but prostitution is, seems somewhat inconsistent: all have sellers and buyers; many involve 
physical contact; many pose a danger that one or more persons could be hurt in some capacity, whether physically, emotionally, or financially. However, as society generally allows for "questionably moral" or "ugly" firms, actors, sellers, and buyers to operate with some constraints, and as it generally deems that people have the right to do what they want with their property (in this case, the prostitute's body and the labor resulting therefrom), even in the face of potential negative externalities, perhaps a detailed analysis can offer some reconciliation to the benefit of all parties concerned.

\section{The Neoclassical Model}

Let us stipulate that prostitution is similar in nature to other markets. Based upon the theory of bounded rationality, an integral aspect of the neoclassical model, both parties who engage in an exchange must feel that they have adequate information to make an informed and rational decision regarding whether or not to engage in the transaction. "Exchange" and "transaction" hereafter will refer to the transfer of money for sex; though, obviously, there are many variations of this scenario, including other forms of payment, e.g., drugs or protection, and various types of sexual services.

There are several problems that may arise from this exchange, particularly those dealing with asymmetric information (the prostitute knows he or she has a sexually transmitted disease (STD) while the solicitor does not), as well as transaction costs, including paying for a "pimp" or hired protection in a brothel. But, relative to any other market, there is little evidence to suggest that these exceptions are any more problematic or occur with any more frequency than the failures or shortcomings that result when one unknowingly buys a car with faulty brakes or when an establishment that serves liquor must hire "bouncers." Therefore, aside from the moral argument, there must be some good economic evidence that validates prostitution's persistent illegality. It is true that many other industries have high costs associated with negative externalities, such as certain manufacturing, which omits excessive pollution; yet, there is still a market for allowing these businesses to practice such unsavory activities. This paper now turns to prostitution's largest and most tangible costs and benefits.

\section{Economic Costs}

If prostitution were legalized, the first major cost to taxpayers would likely be the cost of regulation; this may include the cost to develop and maintain new administrative offices for the purpose of overseeing licensing and fees and sending agents to perform routine checks. Many of the costs would depend upon the degree of regulation the states decide to implement; regulations would likely vary from state to state. For purposes here, we will assume regulations would be similar to those pertaining to pornography; of all the "morally ambiguous" markets mentioned above, this is most similar to prostitution in composition and scope.

It is remarkably difficult to find state budgets for offices or agencies that regulate pornography, but the most comprehensive data come from Los Angeles County, California, which recently began regulating condom usage among actors.

Measure $\mathrm{B}$ requires that male porn actors wear condoms, and producers must obtain a permit from the Los Angeles County Department of Public Health in order to film sex scenes. "[T]he two-year cost of the measure would be a minimum of \$582,932" (Garner 2012). Since, according to the U.S. Geological Survey, there are 3,141 counties (or county-equivalent governments) (U.S. Geological Survey 2013), we can figure that, if every county has some sort of permit processing office, it may cost taxpayers $\$ 915,494,706$ per year to regulate prostitution $[(\$ 582,932 \mathrm{x}$ 3,141 counties)/ 2 years].

This is likely a very high estimate for several reasons and will be modified to 
suit this analysis. First, it is quite doubtful that every single county in the US would allow prostitution, just as not all counties in the state of Nevada permit it. Furthermore, many counties are probably not large enough to warrant any real market for the activity; many would-be participants are probably content to go out of their county to solicit. Just as dry counties still exist and therefore do not need the services of state liquor licensing offices, so too could the regulation of prostitution be concentrated at the state level. Since Los Angeles County is a relatively large county, and most of the pornography that is produced in California is produced there, it could be viewed more accurately as the epicenter of the state's pornography industry. It may therefore be more logical to assume a similar scenario for prostitution. Thus, we will consider the 50 states and reach a figure of $\$ 14,573,300$ annually to regulate prostitution $[(\$ 582,932 \times 50$ states)/2 years].

For multiple reasons, this is also not the final cost of regulation. With almost 10 million people and only 4,084 square miles, Los Angeles County is the most densely populated county in the country (Discover Los Angeles 2013). Since the US is more than 3.5 million square miles in area (National Atlas 2013), it would be inaccurate to assume that each state's costs would be confined to such a small area. It is fair to consider that major cities would have offices to oversee regulation. Following this, perhaps a city that features an international airport is an appropriate, objective definition of "major city." There are 149 major cities with international airports in the US (GoMapper 2014); assuming that each of these cities administers prostitution regulation yields an estimate of $\$ 43,428,434$ per year [(\$582,932 x 149 major cities $) / 2$ years $]$. It is this value we rely on for the analysis.

Another potential cost to the state is the loss of revenue due to fines no longer collected from participants. In 2010, there were 62,668 arrests for prostitution and commercialized vice (ProCon 2012). The Bureau of Justice Statistics (2014) defines "prostitution and commercialized vice" as

[t]he unlawful promotion
of or participation in sexual
activities for profit, including
attempts to solicit custom-
ers or transport persons for
prostitution purposes; to
own, manage, or operate a
dwelling or other establish-
ment for the purpose of pro-
viding a place where pros-
titution is performed; or to
otherwise assist or promote
prostitution.

Penalties are quite varied for prostitutes, “johns," pimps, and brothel owners, and depend upon the number of previous arrests, but "[t]he average punishment for being caught patronizing a prostitute for the first time can be a fine of anywhere from $\$ 100$ to $\$ 250 "$ (Criminal Law Lawyer Source 2014).

We assume here that some of those arrested do not end up paying fines due to various circumstances, such as charges never being brought or because of inability to pay. We also recognize that, since fines can be upward of $\$ 100,000$ for pimps and brothel owners (ProCon 2012), but most arrests are of the actual prostitutes and johns, $\$ 100$ to $\$ 250$ is likely an accurate range, which we will then average to $\$ 175$ per arrest. This results in an expected loss of revenue due to failure to collect fines of approximately $\$ 10,966,900$ per year [\$175 x 62,668 arrests].

After much consideration, we have decided that these are the two largest costs associated with legalizing prostitution. Thus begins a discussion of the more nuanced potential costs that could occur depending on how states implement the policy change.

\section{Other Potential Costs}

First, there may be the cost to 
taxpayers to set up "safe houses" or government-run brothels, much as how legalized gambling is sanctioned and run by state governments in the form of lotteries. However, these constructs are likely not within the scope of regulation and are considered only briefly, because there is no proposed legislation that suggests they would be erected. Furthermore, prostitution in Nevada is all privately owned and operated.

Additionally, regarding the possible cost to fund medical offices with personnel to administer and monitor weekly STD checks, this was assumed to have been counted in the section describing the cost of regulation, based upon figures provided by the comparison to pornography.

Also considered was the potential cost (whether borne by the state, prostitute, or brothel) to treat prostitutes with STDs; however, indications suggest that this figure would be remarkably low. In the case of the analogous pornography industry, data on STD rates in Los Angeles County from the California Department of Public Health show that "[l]ess than one HIV infection per year occurs among adult film performers" (Garner 2012). Similarly, data suggest that rates would not be significantly higher for prostitutes. Even as it is now, with prostitution mostly illegal, and thus not regulated, "[t]he U.S. Department of Health [and Human Services] consistently reports that only 3-5 percent of the sexually transmitted disease in this country is related to prostitution (compared with 30-35 percent among teenagers)" (Prostitutes' Education Network 2004).

It is worth mentioning that conversely considered, but ultimately not utilized, was the possibility of counting STD outcomes as a benefit due to the reduction of STDs resulting from better monitoring and availability of treatment. It is quite plausible that better and earlier disease identification, preventive measures, such as the enforced use of condoms, and reduced spread due to strict liability would actually negate more expensive treatment and would thus result in an overall reduction in cost. However, rates are likely negligible. Consider Nevada, where:

[p]rostitutes are required to
be tested weekly for STDs
and monthly for HIV and
syphilis. Since 1988, con-
doms became mandatory
for oral sex and intercourse
with all sex workers. Brothel
owners are liable if a cus-
tomer becomes infected with
HIV after visiting one of
their prostitutes. Since 1986,
no full-time commercial sex
worker has been tested posi-
tive for HIV (Giang 2011).

If we assume other states would use measures such as those enacted in Nevada, we may see a slight reduction in STDs. Nonetheless, since rates among prostitutes are already so low, it is not considered a major cost or benefit.

Also of interest was the potential increased cost to treat prostitutes' substance abuse issues and psychological trauma due to the likelihood of more prostitutes coming forward and seeking treatment. One could also argue that this cost could just as likely decrease, because prostitutes would be less likely to be physically or psychologically abused, as the whole market would become more transparent and monitored. Put simply, the inference here is that legalizing prostitution (at least in this implied sense, at regulated brothels, with treatment options for various inherent or acquired maladies) leads to prostitutes' increased willingness to seek help without fear of retribution, which also leads to prostitutes' decreased victimization and savings in the long-term because fewer prostitutes are abused or self-inflict harm. Similarly related is the benefit of the reduced cost of crimes often associated with prostitution, such as drug dealing 
and kidnapping, because transactions are no longer obscured by the black market, which are typically characterized by high levels of related crime.

A final consideration was the cost of the requisite increase in police presence in designated areas where prostitution occurs. However, police may also spend less time monitoring prostitution if they know where it is occurring and what law enforcement's role is.

These examples are, of course, neither exclusive nor exhaustive, but none seem to warrant extensive further investigation as they mostly occur in secondary markets and are quite difficult to quantify as directly attributable to legalizing prostitution.

\section{Economic Benefits}

Among the most appealing and indisputable benefits of legalization would be decreased arrest rates and the decreased cost to prosecute and incarcerate prostitutes, johns, pimps, and brothel owners. On the other hand, since many of these arrests result in fines rather than incarceration, one could argue that a main impetus for illegality is to raise revenue, which, as mentioned previously, could be considered a cost to the state if those fines are no longer collected. However, it appears that benefits still exceed costs, as the average cost to arrest and prosecute is about $\$ 4,324$ per case (Pearl 1987), which is obviously much more per case than the typical fine collected. When this figure is multiplied by the number of arrests per year, and the taxpayers potentially save $\$ 270,976,432$ per year [\$4,324 x 62,668 arrests].

It is feasible to consider that because most arrests are not prosecuted, and because law enforcement may also consider tradeoffs and not always spend $\$ 4,324$ to pursue a $\$ 175$ fine, this may be an upper bound estimate of the savings. However, given that there are so many arrests that do not end in prosecution but are still costly, we feel that this is a reasonable estimate.

Another possible benefit of legalizing prostitution is the reduction of rape, as many reliable studies suggest that it would actually decrease the incidence of rape and other violence. For example,
[i]t is estimated that if prostitution were legal- ized in the US, the rape rate would decrease by roughly 25 percent for a decrease of approximately 25,00o rapes per year.... [T]he analysis seems to support the hypoth- esis that the rape rate could be lowered if prostitution was more readily available. This would be accomplished in most countries by its legal- ization (Cundiff 2004, 2-3).

If we accept this figure, either because it is logical that many of those committing the rapes would seek legal outlets in the form of prostitutes, or because most of those rapes liable to cease already occur within the prostitute population due to unsafe circumstances, we should multiply this reduction by the average cost of a rape or sexual assault; this is the sum of the victim cost per incident and the criminal justice cost per incident and is valued at $\$ 142,175$ (Boardman et al. 2011). Therefore, reduction of rape would lead to a benefit to society of approximately $\$ 3,554,375,000$ per year $[\$ 142,175$ $\mathrm{x}$ 25,000 fewer rapes].

One of the largest benefits of legalizing prostitution comes in the form of increased revenue for the states, which may compensate for the loss of fines. In Nevada, "the fees [assessed by the state on legal brothels] range anywhere from $\$ 200$ (Lander County) to $\$ 100,000$ (Storey County) per year" (Giang 2011). Again, we are using Nevada as the template. "Counties that have populations under 700,000 are allowed to operate licensed brothels. Currently, only eight 
Nevada counties have active brothels" (Tan 2012). The population limit only applies to Clark County (home of Las Vegas), which contains nearly 73 percent of Nevada's total population (U.S. Census Bureau 2014a). Nevada has 17 counties overall (State of Nevada 2014). As of August 2013, 19 brothels were operating in Nevada (Vekshin 2013).

If we assume a similar ratio for the other states, we find that if brothels exist in 47 percent of all counties [8 counties with prostitution/17 counties in Nevada], at a rate of 2.4 brothels per active county [ 19 brothels/ 8 counties], there would be 3,543 brothels in the country [. $47 \mathrm{x} 3,141$ counties in the US $\mathrm{x}$ 2.4 brothels per county].

Therefore, we find that total revenue for the states could range anywhere from $\$ 708,600$ [ $\$ 200 \times 3,543$ brothels] to $\$ 354,300,000$ [ $\$ 100,000 \times 3,543$ brothels] per year. For this analysis, we will average those two figures for total expected revenue of $\$ 177,504,300$ per year $[(\$ 708,600+\$ 354,300,000) / 2]$. We realize that many factors are not taken into consideration here; there may be significantly more or fewer brothels in the nation, especially when market saturation is considered, and the population makeup and tendencies of individual states may differ meaningfully. However, Nevada is the only state upon which to base estimates; furthermore, Nevada is a relatively average state with regards to other variables, such as median household and per capita incomes, population growth, median home value, and age distribution (U.S. Census Bureau 2014b). Another increased revenue source is excise taxes. For example, in 2005 in Nevada, prostitutes in brothels "had an unlikely ally in an antiprostitution lawmaker who sponsored a measure proposing a tax of about two dollars per customer. It was expected to bring some $\$ 3.2$ million to the state over the next two fiscal years" (Hennessey 2005). Calculating that, if all 50 states were to legalize prostitution, taxes from the johns alone would be approximately $\$ 80,000,000[(\$ 3,200,000 \times 50$ states)/2 years].

It is worth noting that this assumes a similar number of visits across all states; however, Nevada accounts for only 0.88 percent of the country's total population, which is less than the expected 2 percent share if states' populations were homogeneous. Applying this, we would expect that most states would experience a greater volume of visitors, leading to more revenue, so this model may underestimate the correct figure. However, we must also consider that many of those who patronize brothels in Nevada come from other states. Under the proposed policy of nationwide legalization of prostitution, the figure used here would likely decrease. As highlighted throughout this article, it is very difficult to do any calculations regarding supply and demand or market saturation because the market only exists (legally) in one state.

Additionally, prostitutes would pay income taxes, and brothels would pay corporate taxes. Prostitutes in brothels are considered independent contractors; they therefore are not eligible for unemployment, retirement, or health benefits. They do, however, pay a federal income tax (Flowers 2011).

Compiling data regarding how many hours prostitutes work per week has proven somewhat difficult. For example, a study from Australia found that

[a] third of the prostitutes work 25 to 36 hours a week, or, as brothel workers, three to four days a week. Less than a fifth work the 'normal' working week of 37 to 48 hours, or, in a brothel, five to six days a week. More than a fifth work 49 to 60 hours a week, although as brothel workers they are probably 
doing three or four days of double shifts (Perkins 1991).

Ignoring the tiny fraction of prostitutes surveyed in the study who either claimed to work more than 84 hours per week or declined to offer a number, this averages out to approximately 33 hours per week.

Some of the best estimates of ranges come from a Business Insider interview with Dena, a "madam" at Sheri's Ranch in Pahrump, Nevada. "Girls at the Ranch work one 'tour' at a time, a contractual stay at the Ranch that can last five days on the short end and up to two weeks or longer. When they're on the clock, the girls work 12-hour shifts, either 5 a.m. to 5 p.m. or vice versa" (Love 2013). One prostitute, Amber Lynn, splits her time evenly between being with her boyfriend in Florida and working full time at Sheri's-two weeks on, two weeks off. Finally, according to the Sheri's Ranch website, "[o]ur Ladies book in for a minimum of one week up to a maximum of three weeks" (Sheri's Ranch 2014).

Also complicating estimates is the possibility that billable hours per week may not be reflected in the figures mentioned above. For example, bookings (time spent actually engaged in the services provided) are likely heavily concentrated at night and on weekends, and the prostitutes may spend several hours per shift maintaining their rooms, grooming themselves, greeting patrons, negotiating fees, or attending to basic bookkeeping.

Given these statistics, we feel it is reasonable to assume that the hours for which the prostitute is paid average out to be 80 hours per month [two weeks worked (average of 1 to 3 weeks worked per month) x 40 hours per week (12-hour shifts x 5 working days per week, with four hours of each shift going to nonpaid activities)].

Though brothels' websites consistently refrain from discussing prices, the average price per hour seems to be around $\$ 800$. "Prices for sexual services typically begin at $\$ 200$ per 15 minutes, but can go higher," with some clients paying $\$ 2,000$ per hour for a standard session, and $\$ 10,000$ or more per hour for "parties" with multiple or well-known prostitutes (Flowers 2011, 44). Dennis Hof, owner of the Moonlite Bunny Ranch, said his customers spend an average of $\$ 200$ to $\$ 600$ (Vekshin 2013). If that averages to $\$ 400$ per engagement, and the typical engagement lasts under thirty minutes (Nakajima et al. 2010), we find that clients probably do pay at least $\$ 800$ per hour on average. [ $\$ 400 \times 230-m i n-$ ute periods in an hour]. Of course, we realize that prostitutes likely will not engage with clients for every consecutive 30-minute period, but this was accounted for in the above calculations regarding billable hours. Furthermore, this seems like a reasonable figure to use for this analysis, because prostitutes often earn much more. "[Y]ou can expect to spend anywhere from a few hundred dollars on the basic side of things to thousands of dollars and more at the other end of the spectrum" (Love 2013).

It is standard practice for prostitutes to keep half of what they make, while the "house" gets the other half (Vekshin 2013). Therefore, each prostitute nets $\$ 400$ per hour. That is $\$ 384,000$ in federally taxable income $[\$ 400 \times 80$ hours per month x 12 months per year], which puts him or her in the third highest income bracket, with a marginal tax rate of 33 percent and an average tax rate of about 29 percent (assuming he or she is filing individually) (Small Business Taxes \& Management 2014). That is a benefit of $\$ 111,360$ [ $\$ 384,000 \times$.29] to the federal government-and therefore to US taxpayers-every year for each prostitute.

In the nineteen legal brothels in Nevada, there are hundreds of prostitutes employed at any given time. A December 2013 article reporting on Nevada prostitutes' ability to attain health insurance for the first time under the Affordable Care Act suggests that many small broth- 
els employ around 15 prostitutes while a few large ones employ up to 500 (Gardner 2013). Given the previous stipulation regarding prostitutes' typical on-off schedule, it is reasonable to assume that only half of a brothel's personnel may be working at any given point in time. We can also imagine that some truly small brothels (employing fewer than five prostitutes) exist without attracting media scrutiny. Therefore, we estimate the median number of prostitutes employed at a Nevada brothel to be 25, for a total of 475 statewide. Again, assuming Nevada would be on par with the average of all states (some states would have more prostitutes, some fewer), we can estimate personal income tax revenues that would be collected by the federal government at $\$ 2,644,800$,000 [ $\$ 111,360 \times 475$ prostitutes $\mathrm{x} 50$ states]. In addition, since most states also utilize an income tax, combined revenues would likely be even higher.

Furthermore, with an average of twenty-five prostitutes per brothel, and the house also receiving $\$ 384,000$ per prostitute per year, most brothels would face both marginal and average tax rates of 34 percent and would thus pay $\$ 3,264,000$ per year [25 prostitutes per brothel x \$384,000 x .34] (Small Business Taxes \& Management 2014). Therefore, brothels would pay $\$ 11,564,352,000$ per year in federal taxes [3,543 brothels in the country x $\$ 3,264,000$ per brothel]. Combined with federal taxes paid by prostitutes, this equates to a total annual federal tax revenue increase of $\$ 14,209,152,000[\$ 11,564,352,000$ from brothels $+\$ 2,644,800,000$ from prostitutes]. Again, where applicable, state income taxes would increase this number. This is the figure used for purposes of this analysis. However, once again, we cannot say whether price or quantity would change if other states legalized prostitution, because we do not know how shifting from the black market would affect these outcomes.

\section{Other Potential Benefits}

Similar to the analysis of potential costs, there are likely several benefits that are not counted here, either because they occur in secondary markets, are too tenuous to assert, or simply have no real way of being quantified. These include the cost of lives saved by reducing murders related to prostitution and treating prostitutes' substance abuse issues. These could be measured by using the value of a statistical life; however, it would be difficult to determine correlation between legalization and the reduction of these tragedies. Equally difficult to directly attribute to legalization, because they occur in secondary and often black markets, would be the reduction of other crimes associated with prostitution.

Also worth mentioning are the potential savings for taxpayers in the form of welfare previously distributed to workers now legally employed. This may be due to the possibility that more people might be drawn to become sellers in this market and would therefore no longer require assistance, or because many people are currently registered as being eligible for welfare but are actually already working as prostitutes and bilking the system. Again, because the black market is obscured, we cannot determine how many people would enter and leave the market nor can we estimate how many claims are fraudulent. Table 1 summarizes the costs, benefits, and overall net benefits of legalizing prostitution on a national scale.

\section{Sensitivity Analysis}

As sensitivity analyses were primarily described and executed within the descriptions of each cost and benefit, and no discount rates were used, a discussion of accuracy can be brief. The most important factor is that many of the figures used are derived from a very ambiguous market, and as such, come with caveats and include rather broad ranges. Thus, the most compelling sensitivity concerns 
Table 1: Summary of Costs, Benefits, and Net Benefit

\begin{tabular}{|l|r|}
\hline Costs \\
\hline Cost to Taxpayers to Regulate Legalized Prostitution & $-\$ 43,428,434$ \\
\hline Cost to Government from Fines No Longer Collected & $-\$ 10,966,900$ \\
\hline Benefits & $\$ 270,976,432$ \\
\hline Benefit to Taxpayers Resulting from No More Arrests/Prosecutions & $\$ 3,554,375,000$ \\
\hline Benefit to Society from the Reduction of Rape/Sexual Assault & $\$ 177,504,300$ \\
\hline Benefit to Government from Fees/Licensing Revenues & $\$ 80,000,000$ \\
\hline Benefit to Government from Excise Taxes & $\$ 14,209,152,000$ \\
\hline Benefit to Government from Combined Federal Income Taxes \\
\hline & \\
\hline Net Benefits & $\mathbf{\$ 1 8 , 2 3 7 , 6 1 2 , 3 9 8}$ \\
\hline
\end{tabular}

could best be addressed by performing calculations similar to a best/worst case scenario. For example, figures such as the range of fines collected for an arrest (from $\$ 100$ for a first-time offender to $\$ 100,000$ for a persistent perpetrator) vary widely. For the sake of brevity, Table 2 shows the very extreme and unlikely low end of the spectrum (worst case) and very extreme and unlikely high end of the spectrum (best case) of the benefits of legalizing prostitution. As these are approximate calculations, a more indepth analysis would certainly include all the combinations of these variations and would provide a more robust analysis.

\section{Applying the Coase Theorem to Value Social Mores and Property Rights}

Having shown that the monetary benefits of legalizing prostitution appear to outweigh the costs, let us turn now to the most challenging aspects of the analysis, and likely the real reasons the practice is not permitted: social mores and a poor delineation of standing in regards to property rights. To what extent does not approving of someone's behavior justify taking away their right to utilize their property as they see fit? In this case, how does one forbid another from selling his or her labor, namely, sexual services? This may seem impossible to quantify, but a solution may be found when we apply the Coase theorem.

We assume that the reader is somewhat familiar with Coase's seminal article "The Problem of Social Cost." From that, the Coase theorem essentially suggests that we consider compensation for the cessation of activities where both parties may have a claim to property rights. There exists a resolvable discrepancy when one party is worse off if the other exercises his or her right to use his or her property as he or she sees fit. Coase's example of a farmer and a cattle-raiser will be modified to suit the discussion here, in consideration of society's possible right to prevent prostitution and the prostitute's possible right to sell his or her services. Regarding prostitution, aside from the negative consequences that affect only the parties directly engaging in the exchange, "there are the problems they are said to cause: a nose-dive in property values [...] noise and litter, [and] associated crimes. Nobody seems to want visible prostitutes in their backyard" (Queen 2000).

Though not nearly as clear as Coase's example of the cattle destroying the farmer's crops, it must be acknowledged that the prostitute's livelihood may 
depend upon his or her trade and that to deny him or her that livelihood would be inflicting harm upon him or her.

The question is commonly thought of as one in which $A$ inflicts harm on $B$ and what has to be decided is: how should we restrain A? But this is wrong. We are dealing with a problem of reciprocal nature. To avoid the harm to $B$ would inflict harm on $A$. The real question that has to be decided is: should $A$ be allowed to harm $B$ or should $B$ be allowed to harm A? The problem is to avoid the more serious harm (Coase 1960, 2).

Just as some would find the erection of a skyscraper in front of their window offensive (and observe the reduction in their property value), this does not necessarily mean that the developer has no right to build on his or her own property; it is not immediately clear that the person whose view is being obstructed has no rights or recourse either. One thing to note about Coase's model is that, depending on the level of regulation instated after legalization, the transaction costs might be very high or very low; it is important to Coase that they are reduced to the extent possible in order to achieve economic efficiency.

In this way, perhaps the parties affected could negotiate the settlement better by determining how much the prostitute earns and how much the property value of the surrounding area is reduced thereby. If it is worth it to the prostitute to continue to engage in his or her trade after compensating the property owners, he or she will continue

Table 2: Worst/Best Case Sensitivity Analysis

\begin{tabular}{|c|c|c|}
\hline & Worst Case & Best Case \\
\hline $\begin{array}{l}\text { Loss of Revenue of Fines No } \\
\text { Longer Collected } \\
\text { ( } \$ 100-\$ 100, \text { ooo per arrest }) \\
\text { x Number of Previous Arrests } \\
(62,668)\end{array}$ & $\$ 6,266,800,000$ & $\$ 6,266,800$ \\
\hline $\begin{array}{l}\text { Raised Revenue from Fees/ } \\
\text { Licensing } \\
\text { ( } \$ 200-\$ 100,000 \text { per brothel) x } \\
\text { Number of Brothels }(3,543)\end{array}$ & $\$ 708,600$ & $\$ 354,300,000$ \\
\hline $\begin{array}{l}\text { Personal Income Tax Benefits } \\
\text { Hours Worked (40-120 per month) } \\
\text { x Rate for the Prostitute ( } \$ 400 \text { per } \\
\text { hour) x Tax Rate (dependent upon } \\
\text { income bracket) }\end{array}$ & $\begin{array}{c}\$ 1,140,000,000 \\
\\
{[475 \text { Prostitutes x 5o states }} \\
x \$ 48, \text { ooo per prostitute } \\
\text { per year }(\$ 192, \text { ooo per } \\
\text { year taxed at } 25 \%)]\end{array}$ & $\begin{array}{c}\$ 4,377,600,000 \\
{[475 \text { Prostitutes } x 50} \\
\text { states } x \$ 184,320 \text { per } \\
\text { prostitute per year } \\
(\$ 576, \text { ooo per year taxed } \\
\text { at } 32 \%)]\end{array}$ \\
\hline $\begin{array}{l}\text { Corporate Income Tax } \\
\text { Hours Worked (40-120 per month) } \\
\text { x Rate for the Brothel ( } \$ 400 \text { per } \\
\text { hour) x Prostitutes per Brothel x } \\
\text { Tax Rate (dependent upon income } \\
\text { bracket) }\end{array}$ & $\begin{array}{c}\$ 5,782,176,000 \\
\\
{[3,543 \text { Brothels } x(\$ 192,000} \\
\text { per prostitute per year } x \\
25 \text { prostitutes per brothel } \\
\text { taxed at } 34 \%)]\end{array}$ & $\begin{array}{c}\$ 17,346,528,000 \\
\\
{[3,543 \text { Brothels } x} \\
(\$ 576,000 \text { per prostitute } \\
\text { per year x } 25 \text { prostitutes } \\
\text { per brothel taxed at } 34 \%)]\end{array}$ \\
\hline Net Benefits & $\$ 4,518,007,598$ & $\$ 25,934,084,198$ \\
\hline
\end{tabular}


to do so. If, however, it is worth it to the property owners to know that there are no prostitutes operating in their vicinity, they would have to compensate the prostitutes not to pursue their activities. "All solutions have costs and there is no reason to suppose that government regulation is called for simply because the problem is not well handled by the market or the firm" $(1960,18)$.

Adam Ozimek (2010) offers an effective example:

Say Ray's friend Lenore wants to purchase Ray's prostitution services and she values them at \$40o. But when Lenore does this it bothers Ray's other friend Tonya. If the negative utility Tonya experiences is worth more than $\$ 400$, then the market provides a mechanism for Tonya to satisfy her wants: she can pay Ray \$401 not to sleep with Lenore.

You might argue that contracts aren't complete enough to guarantee that Ray won't sleep with Lenore anyway the moment Tonya turns her back. But what Tonya can buy from Ray for $\$ 401$ is only an hour of not sleeping with Lenore, because that is what one hour of his time is worth. If she wants to pay Ray to never sleep with Lenore she has to pay the net present value of all of the future services.

For those who morally object when Ray sells himself to anyone, not just Lenore, this is a moot point because there are other clients anyway, so paying to not sleep with Lenore doesn't accomplish much less prostitution. The point is that because prostitutes offer a flow of services Tonya has to pay Ray not to sleep with all of his potential clients if she wants him to not be a prostitute. Essentially she has to buy the entire flow of services.

This makes contracting much less simple: if you don't like prostitution then you can hire the prostitute to do something else. In this way the presence of lots of people who object for any reason, moral or otherwise, to prostitution can drive down the quantity of prostitution services by bidding up their price. What this means is that markets are fully capable of internalizing the mental costs borne by those who dislike prostitution.

Coase goes on to note that, though he believes economists and policymakers "have tended to over-estimate the advantages" of government by simply making a transaction illegal, this does no more than "suggest that government regulation should be curtailed. It does not tell us where the boundary line should be drawn" (Coase 1960, 18). He quotes William Prosser regarding tort law:

[A] person may 'make use of his own property or [...] conduct his own affairs at the expense of some harm to his neighbors. He may operate a factory whose noise and smoke cause some discomfort to others, so long as he keeps within reasonable bounds. It is only when his conduct is unreasonable, in light of its utility and the harm which results [empha- 
sis added], that it becomes a nuisance' (1960, 19).

Perhaps a reasonable compromise would be to arrange a specific area where prostitutes could practice their activity, such as in the case of Nevada. Similar to the cattle-raiser paying the farmer not to grow crops on a certain tract of land, whether the community pays the prostitute not to practice his or her trade except in an agreed-upon area or the prostitute pays the community to be permitted to practice in a designated area is not of importance at this point; the key is that a complete economic analysis would indicate total allocation of resources and transaction costs. From that point, "[w]hat payment would in fact be made would depend on the shrewdness of the farmer and the cattle-raiser as bargainers" $(1960,5)$.

It seems that "[t]he same levels of production are achieved whether the perpetrator of the negative externalities is legally liable for the externality costs or if [sic] the victims of the negative externalities make a payment to the perpetrator that is reduced by the amounts of the externalities" (Watkins 2014). Thus, assuming that the prostitute probably has some right to practice his or her trade, and, as shown by the previous calculations, it is actually more economically efficient for the transaction to be legalized, we may apply the Coase theorem in order to determine where particular costs and benefits may lie. Whether on the side of taxpayers and the government or with the prostitute, the bottom line is that monetary amounts may be counted in one column or the other, but they are not eliminated; society reaps net benefits.

\section{Conclusion}

Though this assessment is in no way comprehensive, it is our hope and policy recommendation that the conversation regarding legalizing prostitution be revisited, if for no other reason than to consider how economic efficiency may be increased. Ultimately, the best way to deal with most potential objections seems to be to offer the rebuttal that "bad things" are occurring anyway in the illegal market. If anything, it would seem that shedding light and offering transparency would help to identify and assist the people who are most susceptible to these dangers.

As shown through this analysis, there is no reason to think that the costs of legalizing prostitution would outweigh the benefits. Though one can never anticipate all the exigent circumstances accompanying such a vast policy change, legalizing prostitution would likely not be any more fraught with insurmountable challenges and complications than was legalizing alcohol. The argument against legality seems to be one based upon personal preferences and tendencies to eschew seemingly anti-social behavior. When questioning Pigou's definition of actions that are not particularly desirable to a community, Coase states, "But he is wrong when he describes these actions as 'anti-social.' They may or may not be. It is necessary to weigh the harm against the good that will result. Nothing could be more 'anti-social' than to oppose any action which causes any harm to anyone" (Coase 1960, 35).

\section{References}

Block, Walter. 2008. Defending the Undefendable. Auburn, AL: Ludwig von Mises Institute.

Boardman, Anthony E., David H. Greenberg, Aidan R. Vining, and David L. Weimer. 2001. Cost-Benefit Analysis: Concepts and Practice. 4th ed. Upper Saddle River, NJ: Prentice Hall. 
Bureau of Justice Statistics. 2014. “Definitions and Terms.” Accessed March 20, 2014. http://www.bjs.gov/arrests/templates/terms.cfm.

Coase, Ronald H. 1960. "The Problem of Social Cost." The Journal of Law and Economics 3: 1-44.

Criminal Law Lawyer Source. 2014. “Prostitution.” Accessed March 20, 2014. http:// www.criminal-law-lawyer-source.com/terms/prostitution.html.

Cundiff, Kirby R. 2014. "Prostitution and Sex Crimes.” The Independent Institute. Accessed March 20, 2014. http://www.independent.org/pdf/working_papers/50_prostitution.pdf.

Discover Los Angeles. 2013. "Facts About Los Angeles." Last modified March 5, 2013. http://www.discoverlosangeles.com/press-releases/facts-about-los-angeles.

Flowers, R. Barri. 2011. Prostitution in the Digital Age: Selling Sex from the Suite to the Street. Santa Barbara, CA: Praeger.

Gardner, Tom. 2013. “At Least Someone’s Happy! Nevada’s Legal Prostitutes Say They Can Finally Get Health Insurance Thanks to Obamacare (But the Brothels' Owner Says It Will Cost Him a Fortune).” Daily Mail. Accessed March 20, 2014. http://www.dailymail.co.uk/news/article-2516856/At-someones-happy-Nevadas-legal-prostitutes-say-finally-health-insurance-thanks-Obamacarebrothels-owner-says-cost-fortune.html.

Garner, Alex. 2012. “The Numbers Don't Add Up on Measure B.” The Huffington Post. Accessed March 20, 2014. http://www.huffingtonpost.com/alex-garner/thenumbers-dont-add-up-on-measure-b_b_2074065.html.

Giang, Vivian. 2011. "Everything You Ever Wanted to Know About Prostitution in Nevada.” Business Insider. Accessed March 20, 2014. http://www.businessinsider.com/prostitution-legal-nevada-prostitutes-brothels-sex-2011-12?op=1.

GoMapper. 2014. "List of International Airports in United States of America.” Accessed March 20, 2014. http://www.gomapper.com/travel/list-of-international-airports-in/united-states-of-america.html.

Hennessey, Kathleen. 2005. "Nevada Brothels Want to Be Good Neighbor.” Associated Press. Accessed March 20, 2014. http://www.scapa-lv.org/news/Nevada\%20 Brothels\%20Want\%20to\%2oBe\%20Good\%2oNeighbor.htm.

Love, Dylan. 2013. "I Walked Into a Nevada Brothel and My Expectations Were Shattered." Business Insider. Accessed March 20, 2014. http://www.businessinsider.com/inside-a-nevada-brothel-2013-10.

Nakajima, Koichi, Koichi Nagao, Toshihiro Tai, Hideyuki Kobayashi, Hiroshi Hara, Kazukiyo Miura, and Nobuhisa Ishii. 2010. "Duration of Sexual Intercourse Related to Satisfaction: Survey of Japanese Married Couples.” Reproductive Medicine and Biology 9: 139-144.

National Atlas. 2013. "Profile of the People and Land of the United States." Last modified January 14, 2013. http://nationalatlas.gov/articles/mapping/a_general. html.

Ozimek, Adam. 2010. “The Visceral Externality of Prostitution.” Modeled Behavior. Accessed March 20, 2014. http://modeledbehavior.com/2010/11/o4/thevisceral-externality-of-prostitution/.

Pearl, Julie. 1987. “The Highest Paying Customers: America's Cities and the Costs of Prostitution Control." Hastings Law Journal 38: 769-80o.

Perkins, Roberta. 1991. Working Girls: Prostitutes, Their Life and Social Control. Canberra: Australian Institute of Criminology. 
ProCon. 2012. "US and State Prostitution Arrests, 2001-2010." Last modified December 4, 2012. http://prostitution.procon.org/view.resource. php?resourceID=000120.

Prostitutes' Education Network. 2014. "Prostitution in the United States-The Statistics.” Last modified October 13, 2004. http://www.bayswan.org/stats.html.

Prostitution Nevada. 2014. "Nevada Prostitution Laws.” Accessed March 20, 2014. http://www.prostitutionnevada.com/prostitution-laws-nevada/.

Queen, Carol. 2000. "Sex in the City." San Francisco Chronicle. Accessed March 20, 2014. http://www.sfgate.com/news/article/Sex-in-the-City-Street-prostitutesdriven-by-2695617.php\#ixzz24nQh8qBE.

Sheri's Ranch. 2014. "Employment.” Accessed March 20, 2014. http://www.sherisranch.com/employment.aspx.

Small Business Taxes \& Management. 2014. "Corporate and Individual Tax Data.” Last modified January 27, 2014. http://www.smbiz.com/sbrloo1.html.

State of Nevada. 2014. "County and City Government Directory.” Accessed March 20, 2014. http://nv.gov/government/county-city/.

Tan, Edward. 2012. "Should the U.S. Legalize Prostitution?” FindLaw. Accessed March 20, 2014. http://blogs.findlaw.com/blotter/2012/04/should-the-us-legalizeprostitution.html.

U.S. Census Bureau. 2014a. "Clark County QuickFacts.” Last modified January 6, 2014. http://quickfacts.census.gov/qfd/states/32/32003.html.

. 2014b. "Nevada QuickFacts." Last modified January 6, 2014. http://quickfacts. census.gov/qfd/states/3200o.html.

U.S. Geological Survey. 2013. "How Many Counties Are There in the United States?" Last modified January 9, 2013. http://gallery.usgs.gov/audios/124\#.UwPRqkJdXii.

Vekshin, Alison. 2013. "Brothels in Nevada Suffer As Web Disrupts Oldest Trade." Bloomberg. Accessed March 20, 2014. http://www.bloomberg.com/ news/2013-08-28/brothels-in-nevada-shrivel-as-web-disrupts-oldest-trade. html.

Watkins, Thayer. 2014. "Illustration of the Coase Theorem.” San José State University Department of Economics. Accessed March 20, 2014. http://www.sjsu.edu/ faculty/watkins/coasetheorem.htm.

Malia Dalesandry graduated from Ohio University with a Bachelor of Fine Arts in dance before bartending in New York City and Los Angeles for many years and then finally receiving her Master of Public Policy at the George Washington University in Washington, DC. Preparing to enter the public policy PhD program at George Mason University in the Fall of 2014, she believes that the best way to advocate improvement is not through political forces, but rather through intellectual ones.

The author thanks Brandon Kruse, Tanya Harris Joshua, and especially Christine Mellen for their dedication throughout the publication process, as well as faculty editor, professor, mentor, and friend Susan Dudley for her ongoing encouragement. She would also like to thank her mother and brother for their love and support, and especially her father, Michael "Del” Dalesandry (1949 - 2008), who originally instilled in her the intrinsic value of individual liberty. 